\section{KISA BILLDIRIM}

Tuba Erdem Sultanoğlu ${ }^{1}$

Safinaz Ataoğlu ${ }^{1}$

${ }^{1}$ Düzce Üniversitesi Tıp Fakültesi, Fiziksel Tıp ve Rehabilitasyon Anabilim Dalı, Düzce, Türkiye

Yazıșma Adresi:

Tuba Erdem Sultanoğlu Düzce Üniversitesi Tip Fakültesi, Fiziksel Tip ve Rehabilitasyon Anabilim Dall, Düzce, Türkiye mail:drtubaerdem@gmail.com

Geliș Tarihi: 18.06.2020

Kabul Tarihi: 16.07.2020

DOI: $10.18521 / \mathrm{ktd} .754390$

Konuralp Medical Journal e-ISSN1309-3878

konuralptipdergi@duzce.edu.tr konuralptipdergisi@gmail.com www.konuralptipdergi.duzce.edu.tr

\section{Covıd-19 Pandemi Sürecinde Düzce Üniversitesi Tıp Fakültesi Fiziksel Tıp ve Rehabilitasyon Anabilim Dalı}

\section{ÖZET}

Çin'in Wuhan kentinde ortaya çıkan ve tüm dünyayı etkisi altına alan COVID-19 koruyucu tedbirlerin hızlıca alınması gereken olağanüstü dönemlerden birisidir. Coronavirus Hastalığı (COVID-19), hastalarda başta solunumsal olmak üzere, fiziksel, psikolojik ve yaygın sistemik işlev bozukluğuna yol açan, sosyal yaşantımızda hızlı bir değişikliğe neden olan oldukça bulaşıcı bir hastalıktır. $\mathrm{Bu}$ derlemede Fiziksel Tip ve Rehabilitasyon Anabilim Dalı'ndaki pandemi sürecini anlatmayı amaçladık.

Anahtar Kelimeler: COVID-19, Fiziksel Tip ve Rehabilitasyon, Pandemi

Düzce University Faculty of Medicine Department of Physical Medicine and Rehabilitation in the COVID-19 Pandemic Process

\section{ABSTRACT}

COVID-19 is one of the extraordinary periods in Wuhan, China, which affect the whole world, and protective measures must be taken quickly. Coronavirus Disease (COVID-19) is a highly contagious disease that causes physical, psychological and widespread systemic dysfunction in patients, causing a rapid change in our social life. In this review, we aimed to explain the pandemic process in the Department of Physical Medicine and Rehabilitation.

Keywords: COVID-19, Physical Medicine and Rehabilitation, Pandemic. 
Çin'in Wuhan kentinde ortaya çıkan ve tüm dünyayı etkisi altına alan COVID-19, daha önce insanlarda tespit edilmemiş yeni bir koronavirüs (2019- nCoV) olarak tanımlanmıştır. 2019-nCoV hastalığının adı COVID-19 olarak kabul edilmiş, virüs SARS CoV'e yakın benzerliğinden dolayı SARS-CoV-2 olarak isimlendirilmiştir (1). Mart 2020 tarihinde DSÖ tarafindan pandemi ilan edilmiştir. Coronavirus Hastalığı (COVID-19), hastalarda başta solunumsal olmak üzere fiziksel, psikolojik ve yaygın sistemik işlev bozukluğuna yol açan, sosyal yaşantımızda hızlı bir değişikliğe neden olan oldukça bulaşıcı bir hastalıktır. Hastalığın bulaş yolu, tanısı, klinik özellikleri, tedavisi ve korunma yolları henüz net olarak belirlenmemiştir (2).

10 Mart 2020 tarihinde ilk COVID-19 vakasının Türkiye'de tespit edilmesi ile birlikte Türkiye pandemi planı uygulanmaya başlandı ve tüm ülkede hızlıca önlemler alınmaya başlandı. Bu derlemede Fiziksel Tıp ve Rehabilitasyon Anabilim Dalı'ndaki pandemi sürecini anlatmayı amaçladık.

Sağlık Bakanlığı'nın önerileri doğrultusunda, virüsün yakın mesafede bulunan kişilere damlacık yoluyla bulaşması nedeni ile fizik tedavi uygulamalarına ara verildi. Klinik doktorlarına ve sağlık personellerine virüs bulaşma riskini azaltmak amacıyla esnek mesai uygulamasına yönelik düzenleme yapıldı. Kliniğimizin araştırma görevlileri hastane yönetim kurulu tarafindan pandemi polikliniğinde çalışmak üzere görevlendirildi.

Düzce Üniversitesi Sağlık Uygulama ve Araştırma Merkezi ve hastane yönetimi olarak alınan kararlar ile poliklinik hizmeti durduruldu; böylece polikliniğimize sık başvurusu olan virüse daha hassas gruptaki 65 yaş üstü hastalar korunmuş oldu. Yataklı servisimiz pandemi servisi olarak kullanıldı.

Romatizmal hastalığı olan bireyler, hastalığın kendisinden ve kullandıkları ilaçlara bağlı enfeksiyonların gelişimi ve daha ciddi seyirli olması bakımından COVID-19 açısından risk altındadır. Romatizmal hastalıkların, immünosüpresif veya immünomodülatör tedavi kullanımının SARS-CoV-2 enfeksiyonuna yatkınlık yarattığı veya ciddiyetini arttırdığına dair çalışma şu ana kadar bildirilmemiştir. Ayrıca hastalarımızın tedavisinde kullandığımız bazı immünomodülatör ve biyolojik tedavilerin COVID-19 enfeksiyonunda kullanılmasını destekleyen yayınlar ve öneriler vardır (3). Pandemi sürecinde polikliniğe başvuramadığı için telefon ile bilgi almak isteyen, romatizmal hastalığ 1 olan hastalarımıza güncel veriler 1şığında bilgi verildi. COVID-19 enfeksiyon semptomları olmayan hastalarda ilaç dozu azaltma veya kesme kararı kişiye özel olarak verildi ve yüksek risk kategorisinde olmayan hastalarda ilaç kesilmesine bağlı hastalık alevlenmesi ciddi sonuçlar doğurabileceği için, hastaları remisyonda tutmak amacıyla pandemi öncesinde kullandıkları tedavi rejimlerine devam edildi. Kullanmakta oldukları immünosüpresif, immünomodülatör veya biyolojik tedavileri kesilmedi. Altta yatan komorbiditeleri (ileri yaş, eşlik eden kardiyovasküler veya solunum problemleri, Diabetes Mellitus, hipertansiyon ve sigara kullanımı) olan yüksek riskli grupta ise kullanılan tedavi rejimi, hastalığın tipi veya şiddetine, virüs maruziyet olasılığına göre tedavide geçici ertelemeler yapıldı (4).

1 Haziran 2020'de alınan normalleşme süreci kararlarına uygun olarak kliniğimizde normalleşme başladı. Pandeminin ilk günlerinde ara verdiğimiz fizik tedavi uygulamalarına başlamadan önce fizik tedavi ünitemizde sosyal mesafe kurallarına uygun düzenleme yapıldı. Fizik tedavi ünitesinde görevli personel kişisel koruyucu ekipmanları (koruyucu önlük, maske, siper, eldiven) ile tedavi hizmetine devam ettiler. Fizik tedavi uygulaması öncesinde COVID-19 olası vaka sorgulaması (ateş ölçümü, öksürük ve solunum yolu semptomlar1) yapılmaktadır. Şüpheli vaka sınıfına giren hastalara fizik tedavi uygulanmamaktadır. Tedavi süresince hastaların maskeli olmasına dikkat edilmektedir. Kontaminasyonu engellemek amaciyla tedaviye alınan her hastadan sonra fizik tedavi aletleri uygun şekilde dezenfekte edilmektedir.

\section{KAYNAKLAR}

1. Coronavirus Disease 2019 (Covid-19) Technical Guidance [https://www.who.int/healthtopics/coronavirus\#tab=tab_1].

2. https://covid19bilgi.saglik.gov.tr/depo/rehberler/covid-19-rehberi/COVID-19_REHBERI_ GENEL_BILGILER_EPIDEMIYOLOJI_VE_TANI. pdf

3. T.C Sağlı Bakanlığı COVID-19 Rehberi. Accessed https://covid19bilgi.saglik.gov.tr/depo/rehberler/COVID-19_Rehberi.pdf on April 16,2020

4. Estimation of the asymptomatic ratio of novel coronavirus infections (COVID-19) Hiroshi Nishiura, Tetsuro Kobayashi, Ayako Suzuki, Sung-Mok Jung, Katsuma Hayashi, Ryo Kinoshita, Yichi Yang, Baoyin Yuan, Andrei R. Akhmetzhanov, Natalie M. Linton. International Journal of Infectious Diseases PII: S1201-9712(20)30139-9. PII: S1201-9712(20)30139-9. https://doi.org/10.1016/j.ijid.2020.03.020.

5. Babaoğlu H. Türkiye Romatoloji Derneği Romatoloji Uzmanları için Koronavirüs (Covid-19) salgını sırasında hastalık yönetimi önerileri. Ulus Romatol Derg 2020;12(1):1-2. 